\title{
TOXICITY ANALYSIS OF CRAB SHELL CHITOSAN ARGINYLGLYCYLASPARTIC ACID SCAFFOLD MEMBRANE AND ITS EFFECT ON HUMAN DENTAL PULP CELL VIABILITY
}

\author{
TRI KURNIA DEWI ${ }^{1}$, MAULDINA SHABRINA ${ }^{1}$, DEWI FATMASUNIARTI ${ }^{2}$, LISA AMIR ${ }^{2}$, ERIK IDRUS ${ }^{2 *}$ \\ ${ }^{1}$ Department, Faculty of Dentistry, Universitas Indonesia, Jakarta, Indonesia. ${ }^{2}$ Department of Oral Biology, Faculty of Dentistry, \\ Universitas Indonesia, Jakarta, Indonesia. Email: erik.idrus31@ui.ac.id
}

Received: 16 September 2017, Revised and Accepted: 3 October 2017

\section{ABSTRACT}

Objective: Crab shell chitosan is a biomaterial used for scaffolding. In Indonesia, Badan Tenaga Nuklir Nasional has made a crab shell chitosan arginylglycylaspartic acid (RGD) scaffold membrane. The purpose of adding RGD was to enhance cell attachment to the scaffold.

The objective of this research is to analyze the toxicity of crab shell chitosan RGD scaffold membrane on human dental pulp cells and its effect on their viability.

Methods: Human dental pulp cells were cultured for 5 days in Minimum Essential Medium Alpha ( $\alpha$-MEM) complete containing amphotericin B, penicillin, streptomycin, and fetal bovine serum. Then, the treatment group was exposed to crab shell chitosan RGD scaffold membrane and crab shell chitosan scaffold membrane incubated for $24 \mathrm{~h}$. The toxicity of the crab shell chitosan RGD scaffold membrane was analyzed with a 3-(4,5-dimethylthiazol-2-yl)-2,5-diphenyltetrazolium bromide assay.

Result: The result of this research is that crab shell chitosan RGD scaffold membrane did not decrease the percentage of viability of human dental pulp cells.

Conclusion: It is concluded that crab shell chitosan RGD scaffold membrane does not have toxic effects on human dental pulp cells.

Keywords: Crab shells, Chitosan, Scaffold, Arginylglycylaspartic acid, Toxicity, Human dental pulp cells.

(c) 2017 The Authors. Published by Innovare Academic Sciences Pvt Ltd. This is an open access article under the CC BY license (http://creativecommons. org/licenses/by/4. 0/) DOI: http://dx.doi.org/10.22159/ijap.2017.v9s2.40

\section{INTRODUCTION}

Bone defects can happen due to trauma, periodontal disease, tumors, cysts, and congenital abnormalities, leading to conditions that can change a patient's quality of life [1]. There are a variety of treatments available to cure these conditions.

One such treatment is the use of a bone graft. Bone grafts can be obtained from patients themselves (autograft) or from other animal species (xenograft). Bone grafts have been used for many years and are considered a standard treatment for bone defects; however, autografts show some disadvantages such as insufficient supply and donor site pain [1]. These disadvantages lead to the development of alternative technologies such as tissue engineering. Tissue engineering is a technique that is used for repairing or generating new tissue and consists of three main components: Growth factor, stem cells, and scaffold (Amir et al.). Growth factor is a transcription factor that originates from gene activation during the tissue engineering process [2]. Stem cells are unspecialized cells that have a high proliferation rate and can generate complex tissues and organs [3]. Stem cells can originate from dental pulp [4]. A scaffold is a temporary, extracellular matrix that facilitates cell attachment, cell proliferation, and cell differentiation [5]

One material that can be used as a scaffold is chitosan, the biopolymer derivative of chitin that can be obtained from the exoskeleton of crustaceans such as crab and shrimp. It is biocompatible, biodegradable, and has osteoinductive abilities [6]. However, chitosan lacks bioactive signals that are important for cell attachment, proliferation, and differentiation. For this reason, a chitosan scaffold is often modified with some bioactive molecules such as arginine-glycine-aspartic acid (RGD).
RGD is a cell adhesion peptide that can be found in extracellular matrix proteins such as laminin and collagen. The objective of adding RGD to a chitosan scaffold is to improve cell attachment to the scaffold. Nowadays, Badan Tenaga Nuklir Nasional (BATAN) develops crab shell chitosan RGD scaffold in the form of a membrane combined with RGD. The purpose of forming this scaffold into a membrane is to obtain a scaffold that has high stability when used to repair bone defects, especially large bone defects. However, before this scaffold can be used in tissue engineering, studies must ensure that this scaffold is biocompatible, meaning that this scaffold is nontoxic. The objective of this study is to analyze the toxicity of crab shell chitosan RGD scaffold membrane on human dental pulp cell viability.

\section{METHODS}

In this research, crab shell chitosan RGD scaffold produced by BATAN, Indonesia, was used. The scaffold had the following specifications: In membrane form $(2.5 \mathrm{~cm} \times 1 \mathrm{~cm})$; in white color; degree of deacetylation was $94.5 \%$; viscosity $34.40 \mathrm{cps}$; and $4 \mathrm{mg} \mathrm{RGD} / 50 \mathrm{ml}$ chitosan $2 \%$. The scaffold was produced using a freeze-drying method (Fig. 1). The toxicity of crab shell chitosan RGD scaffold membrane on the viability of human dental pulp cells was analyzed with a 3-(4,5-dimethythiazol-2yl)-2,5-diphenyl tetrazolium bromide (MTT) test. Two kinds of chitosan materials were used: Crab shell chitosan RGD scaffold membrane and crab shell chitosan scaffold membrane without RGD. Crab shell chitosan RGD scaffold membranes with $1 \mathrm{mg}$ and $2 \mathrm{mg}$ concentration, were described in human dental pulp cell cultures and incubated for $24 \mathrm{~h}$. Human dental pulp cell viability was expressed as a percent of the control. Test difference between groups was then analyzed using the one-way analysis of variance test (ANOVA test). 


\section{Cell culture}

First premolar or impacted third molars were removed from patients at the Dental Hospital, Faculty of Dentistry, Universitas Indonesia. The human teeth were soaked in Minimum Essential Medium Alpha $(\alpha$-MEM) complete. Every $50 \mathrm{ml}$ of $\alpha$-MEM complete contains of L-glutamine, ribonucleosides and deoxyribonucleosides with $10 \%$ fetal bovine serum, penicillin $10.000 \mathrm{IU} / \mathrm{ml}$, streptomycin $100 \mathrm{mg}$, and amphotericin B $25 \mu \mathrm{g} / \mathrm{ml}$. Furthermore, the teeth were washed with phosphate buffer saline containing antibiotics. Dental pulp tissue was obtained using an extirpation needle and collected on a petri dish containing $\alpha$-MEM without serum. Human dental pulp cells $\left(10^{6}\right)$ were cultured in a $25 \mathrm{~cm}^{2}$ flask with $\alpha$-MEM complete for up to 5 days. The medium was replaced every 2 days.

\section{MTT}

Toxicity tests were analyzed using MTT. The MTT assay is used as an indirect measure of cell toxicity based on the number of living cells left after being exposed to a test material. Human dental pulp cells, with a density of $2 \times 10^{4}$, were placed on a 96-well plate and cultured for 5 days. With the aim of advancing cell growth, the medium was replaced every 2 days. Next, the treatment group was presented with the crab shell chitosan RGD scaffold membrane with and without RGD (1 mg and $2 \mathrm{mg})$. A 96-well plate was incubated in a $\mathrm{CO}_{2}$ incubator $\left(37^{\circ} \mathrm{C}, 5 \% \mathrm{CO}_{2}\right)$ for $24 \mathrm{~h}$. After incubation, an MTT test was conducted by adding $15 \mathrm{ml}$ solution of MTT ( $5 \mathrm{mg} / \mathrm{ml})$ to all test groups.

Further, incubation in a $\mathrm{CO}_{2}$ incubator $\left(37^{\circ} \mathrm{C}, 5 \% \mathrm{CO}_{2}\right)$ was conducted for $3 \mathrm{~h}$. Next, $100 \mu \mathrm{l}$ of acidified isopropanol was added to each well, followed by incubation at room temperature for $1 \mathrm{~h}$ on an orbital shaker to dissolve the formazan crystals. Samples absorbance values (OD) were read using an enzyme-linked immunosorbent assay reader with a wavelength of $490 \mathrm{~nm}$. Data were corrected with a culture medium without cells (blank value). The experiment was repeated twice on each test group that was at least Duplo. Cell viability was calculated using the following formula:

Cell viability $=($ mean absorbance value treatment group $) /($ average value of absorbance of control group) $\times 100 \%$

\section{Statistical Analysis}

The data were presented as mean values and standard deviations. First, the data were tested using a Shapiro-Wilk normality test. Significant differences in the data were analyzed using a one-way ANOVA test $(\mathrm{p}<0.05)$.

\section{RESULT}

Effect of rotary cell culture system on human dental pulp cells Human dental pulp cells used in this study were cultured for 5 days (Fig. 2).

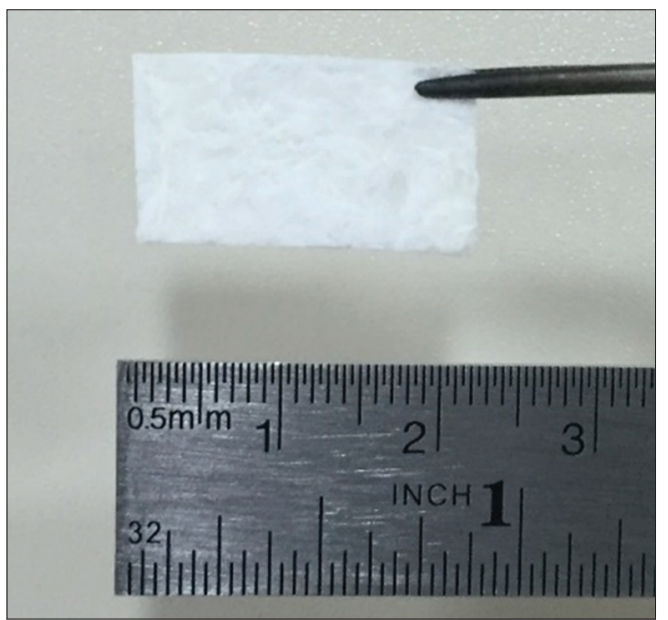

Fig. 1: Crab shell chitosan arginylglycylaspartic acid scaffold
Based on one-way ANOVA statistical analyses, there were significant differences in cell viability between the control group and all chitosantreated groups.

The viability of human dental pulp cells markedly increased after exposure to crab shell chitosan RGD scaffold membrane compared to the control group.

Based on one-way ANOVA statistical analyses, there was a significant difference in cell viability between the crab shell chitosan RGD scaffold membrane $1 \mathrm{mg}$ treated group and the crab shell chitosan scaffold membrane $1 \mathrm{mg}$ treated group $(\mathrm{p}<0.05)$ and between the crab shell

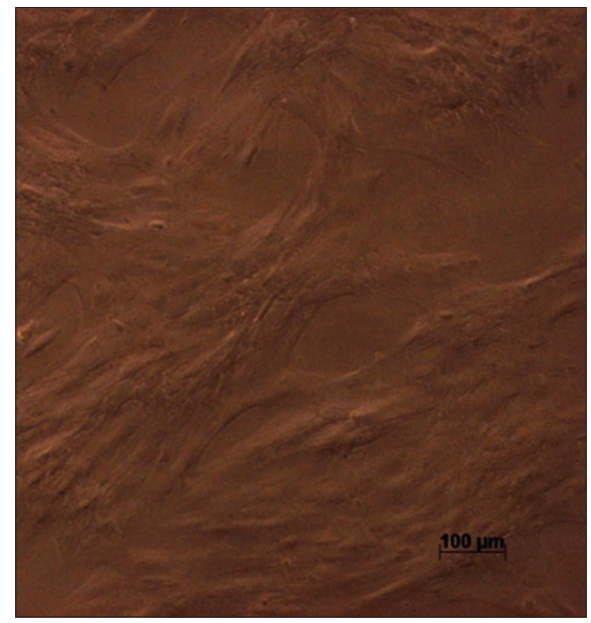

Fig. 2: Microscope image of human dental pulp cell, cultured for 5 days with magnification $\times 10$

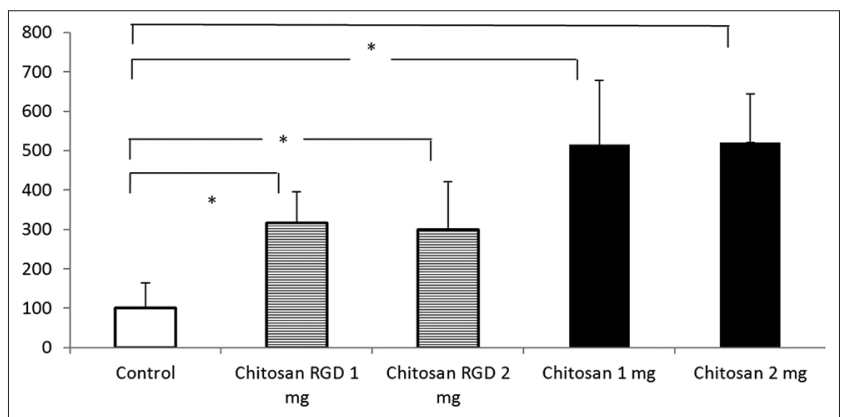

Fig. 3: Optical density value of 3-(4,5-dimethythiazol-2-yl)-2,5diphenyl tetrazolium bromide assay between control group and all chitosan-treated groups (error bars show standard deviation; $* \mathbf{p}<0.05$ )

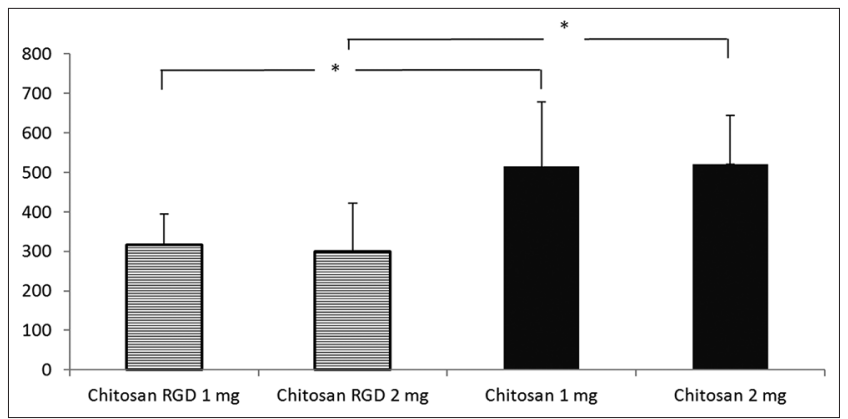

Fig. 4: Optical density value of 3-(4,5-dimethythiazol-2-yl)-2,5diphenyl tetrazolium bromide assay between four chitosantreated groups (error bars show standard deviation; ${ }^{*} \mathbf{p}<0.05$ ) 
chitosan RGD scaffold membrane $2 \mathrm{mg}$ treated group and the crab shell chitosan scaffold membrane $2 \mathrm{mg}$ treated group $(\mathrm{p}<0.05)$.

In larger bone defects, especially one-wall periodontitis defects, the use of bone grafts is ineffective due to disadvantages such as immunology effects that can happen after transplantation [1]. Three decades ago, tissue engineering was developed as an alternative technique to treat larger bone defect [7]. Tissue engineering consists of three major components: Scaffold, stem cells, and growth factor. A material that can be used as a scaffold in bone tissue engineering is chitosan. It is biocompatible, biodegradable, and non-toxic. However, to increase chitosan's efficacy, chitosan needs to be combined with a bioactive molecule such as RGD. A previous study reported that a chitosan scaffold combined with RGD could enhance the attachment and proliferation of osteoblasts in vitro.

In this research, crab shell chitosan RGD scaffold membrane and crab shell chitosan scaffold membrane produced by BATAN, Indonesia, and human dental pulp cells were used. Toxicity analyses were conducted using the MTT assay method. Based on this research, it was determined that crab shell chitosan RGD scaffold membranes did not decrease the cell viability of human dental pulp cells. This result was supported by other research using chitosan scaffolds with and without RGD. A preliminary study also showed that the proliferation of human dental pulp did not decrease after being exposed to a crab shell chitosan RGD scaffold membrane.

Fernandes et al. discovered that chitosan scaffolds were not toxic to rat osteoblasts [8]. Tsai et al. determined that the addition of RGD to chitosan scaffolds stimulated osteoblast cells to proliferate [9]. Prabaharan and Sivashankari found that chitosan scaffolds combined with RGD were not toxic to chondrocyte and fibroblast cells [10]. A study by Chen (2016) showed that the viability of osteoblasts increased after being exposed to chitosan scaffolds combined with RGD [11].

To identify a dose-effect relationship, we used crab shell chitosan scaffold membranes with or without RGD in two different concentrations, $1 \mathrm{mg}$ and $2 \mathrm{mg}$. As seen in Fig. 4, there is no significant difference in cell viability between the crab shell chitosan RGD scaffold membrane $1 \mathrm{mg}$ treated group and the crab shell chitosan RGD scaffold membrane $2 \mathrm{mg}$ treated group and between the crab shell chitosan scaffold membrane $1 \mathrm{mg}$ treated group and the crab shell chitosan scaffold membrane $2 \mathrm{mg}$ treated group.

Fig. 4 also shows that the viability of human dental pulp cells (\%) treated with the crab shell chitosan scaffold membrane $1 \mathrm{mg}$ treated group was significantly higher than the dental pulp cells treated with the crab shell chitosan RGD scaffold membrane 1 mg treated group. Like the $1 \mathrm{mg}$ concentration conditions, the viability of human dental pulp cells (\%) treated with the crab shell chitosan scaffold membrane $2 \mathrm{mg}$ treated group was also higher than the dental pulp cells treated with the crab shell chitosan RGD scaffold membrane $1 \mathrm{mg}$ treated group. Based on a statistical analysis using a one-way ANOVA, the difference was significant.

These results are in agreement with the preliminary study that used crab shell chitosan scaffold membrane and crab shell chitosan RGD scaffold membrane $1 \mathrm{mg}$ and $2 \mathrm{mg}$, indicating that the level of cell proliferation of the human dental pulp cells was higher in the crab shell chitosan scaffold $1 \mathrm{mg}$ group. Based on the data above, the viability percentage of human dental pulp cell treated with crab shell chitosan scaffold membrane without RGD was higher than the viability percentage of human dental pulp cell treated with crab shell chitosan RGD scaffold membrane. This result cannot be explained because only two samples were used in this study, which does not allow for the exploration of a dose and effect relationship.

In clinical applications, membrane scaffolds coat all damaged bone surfaces to transfer nutrients for the cells to achieve localized tissue repair. The addition of RGD to crab shell chitosan scaffold membranes is used to enhance cell attachment to the scaffold along with obtaining a good adhesion to the network. Cell adhesion is the first stage before cells can proliferate. This study shows that the addition of RGD to the crab shell chitosan RGD scaffold membrane did not have toxic effects on human dental pulp cells. In future studies, relations between effects and doses need to be determined to obtain optimal cell numbers and chitosan scaffold membrane levels. When scaffolds and implanted cells are transplanted to areas of bone damage, based on results on these types of studies, cell proliferation and cell differentiation can be ideal.

\section{CONCLUSION}

This study showed that the addition of RGD to the crab shell chitosan membrane did not have toxic effects on human dental pulp cells. Crab shell chitosan RGD scaffold membrane and crab shell chitosan scaffold membrane showed different effects on human dental pulp cells.

\section{ACKNOWLEDGMENT}

This study has been approved by the Research and Ethics Committee, Faculty of Dentistry, Universitas Indonesia. We would like to acknowledge the financial support provided by the Research Center, University of Indonesia, and Hibah Publikasi International Terindeks number 1947/UN2.R12/HKP.05.00/2016.

The publication of this manuscript is supported by Universitas Indonesia.

\section{REFERENCES}

1. Lee M, Li W, Siu RK, Whang J, Zhang X, Soo C, et al. Biomimetic apatite-coated alginate/chitosan microparticles as osteogenic protein carriers. Biomaterials 2009;30:6094-101.

2. Guleria M, Dua H, Rohila S, Sharma AK. Stem cells in dentistry. Indian J Dent Sci 2014;6:107-12.

3. Casagrande L, Cordeiro MM, Nör SA, Nör JE. Dental pulp stem cells in regenerative dentistry. Odontology 2011;99:1-7.

4. Nawi NS, Ariffin Z, Alam MK, Noor SN, Hassan A. The assessment of proliferation rate of dental pulp stem cells and stem cell from human exfoliated deciduous teeth by using two different scaffold. Int Med J 2013;20:593-6

5. Amir LR, Suniarti DF, Utami S, Abbas B. Chitosan as a potential osteogenic factor compared with dexamethasone in cultured macaque dental pulp stromal cells. Cell Tissue Res 2014;358:407-15.

6. Croisier F, Jérôme C. Chitosan-based biomaterials for tissue engineering. Eur Polym J 2013;49:780-92.

7. Bellis SL. Advantages of RGD peptides for directing cell association with biomaterials. Biomaterials 2011;32:4205-10.

8. Fernandes LL, Resende CX, Tavares DS, Soares GA, Castro LO, Granjeiro JM. Cytocompatibility of chitosan and collagen-chitosan scaffolds for tissue engineering. Polimeros 2011;21:1-6.

9. Tsai WB, Chen YR, Li WT, Lai JY, Liu HL. RGD-conjugated UVcrosslinked chitosan scaffolds inoculated with mesenchymal stem cells for bone tissue engineering. Carbohydr Polym 2012;89:379-87.

10. Prabaharan M, Sivashankari PR. Prospect of bioactive chitosan-based scaffold in tissue engineering and regenerative medicine. Chitin and Chitosan for Regenerative Medicine. Springer Series on Polymer and Composite Materials In: Dutta P, editor. New Delhi: Springer; 2016. p. 47-57.

11. Chen YL, Lee HP, Chan HY, Sung LY, Chen HC, Hu YC, et al. Composite chondroitin-6-sulfate/dermatan sulfate/chitosan scaffolds for cartilage tissue engineering. Biomaterials 2007;28:2294-305. 